\title{
ДОСВІД ЗАРУБІЖНИХ КРАЇН У ПОДОЛАННІ НАСИЛЬСТВА В СІМ'ї
}

\author{
області \\ БАКАЇМ Марія Василівна - суддя Золочівського районного суду, Львівської \\ УДК 343.85:347.63 \\ DOI 10.32782/EP.2021.10
}

Обоснована актуальность изучения и учета в нормотворческой деятельности международных стандартов противодействия домашнему насилию. Проанализировано модельное законодательство ООН о домашнем насилии и перспективъ внедрения его норм 8 отечественную практику. Обобщен опьт законодательного обеспечения борьбъ с домашним насилием в странах Европь с точки зрения возможностей его использования в Украине.

Ключевъе слова: предотвращение и противодействие домашнему насилию, международнвие нормативно-правовъе стандарть, законотворчество, международнъий опьлт, защитное предписание.

Постановка проблеми

В Україні у четвірку найчастіших правопорушень входить домашне насилля. Це свідчить про актуальність проблеми та затребуваність іiі вирішення у сьогоденні. Імплементація світового досвіду щодо вирішення цих проблем у Европі є важливим кроком уперед у визнанні України правовою і демократичною країною на міжнародній арені. Тому цілком слушним було те, що Верховна Рада України активно працювала над відповідним законопроєктом, а наприкінці 2017 р. Закон України «Про запобігання та протидію домашньому насильству» став чинним. Він містить багато новел [1, c.131].

Характерною ознакою сучасного поступу вітчизняної юриспруденції в галузі за- безпечення законних прав і свобод людини та громадянина $є$ посилення боротьби 3 домашнім насильством [2; 3]. При цьому основна увага приділяється нормативноправовому забезпеченню охорони особи від домашнього насильства як на рівні законодавчому, так і шляхом затвердження та запровадження підзаконних нормативноправових актів. Зазначена робота проводиться 3 використанням результатів досліджень у відповідній галузі правової науки, узагальненням практичних напрацювань i врахуванням відповідних міжнародних стандартів та зарубіжного досвіду. Відповідно метою статті $\epsilon$ аналіз міжнародних нормативно-правових документів, спрямованих на забезпечення протидії домашньому насильству, й узагальнення відповідного досвіду інших країн, який можна використати для організації нормативно-правового регулювання цього напрямку в нашій державі [4, с.111].

\section{Стан дослідження проблеми}

Питання важливості використання міжнародного досвіду для розвитку національної нормативно-правової бази протидії домашньому насильству та надання допомоги постраждалим розглядалися такими вітчизняними вченими, як О. М. Бандурка, А. Б. Блага, А. О. Галай, В. О. Галай, А. О. Головко, М. О. Качинська, К. Б. Аевченко, В. В. Муранова, С. О. Проневич та інші [5]. 


\section{Виклад основного матеріалу}

Вихідні положення міжнародних стандартів у сфері боротьби з домашнім насильством грунтуються на глибокому усвідомленні неприпустимості подібного насильства, яке $є$ грубим порушенням прав людини. До найбільш важливих міжнародних нормативно-правових документів уважаємо за доцільне віднести Модельний закон ООН про домашнє насильство, ухвалений 2 лютого 1996 року Комісією ООН з прав людини [6].

Модельним законом визначено поняття насильства в сім'ї та сформульовано вимоги до працівників правоохоронних органів, прокуратури і судів, підкреслено важливість безпеки потерпілих під час кримінального та цивільного судочинства. Відповідно до Декларації про цілі закон визначає, що законодавство про домашнє насильство повинне забезпечити максимальний захист жертв домашнього насильства - від фізичного та сексуального до психологічного.

Згідно з вимогами модельного законодавства працівники правоохоронних органів, реагуючи на повідомлення про насильство в сім'ї, «вживають усіх необхідних заходів для гарантування безпеки жертви та iii утриманців». Також у ньому міститься положення про гарантування безпеки під час кримінального судочинства та чітко зазначається, що «під час судового процесу відповідач, звинувачений у насильстві в сім'ї, не повинен мати жодного безконтрольного контакту з позивачем» [6].

Модельне законодавство націлює країни на те, щоб було технологічно прописано дії працівника правоохоронних органів у випадку надходження заяви про факт домашнього насильства, з вимогою щодо належного реагування на кожне прохання про допомогу та захист. Чітко перелічено випадки реагування з виїздом на місце події, до яких віднесено наявність охоронного ордера за можливості його порушення, реальної небезпеки насильства або його посилення, а також наявність фактів насильства в цій родині в минулому. При цьому оперативність реагування на заяву має бути належною також у випадках, коли вона надходить не від жертви насильства, а від іншої особи, якою може бути будь-хто (свідок, друг або подруга, родич або родичка, представник служби охорони здоров'я або центру допомоги потерпілим від насильства тощо) [4, с.112].

До обов'язкових дій працівника правоохоронного органу у випадку реагування на факт насильства в сім’ї віднесено:

- опитування сторін конфлікту без присутності інших осіб;

- докладний запис усіх викладених скарг;

- надання жертві насильства докладних консультацій і роз'яснень ії законних прав;

- складання та реєстрацію документів, передбачених законами та підзаконними нормативними актами.

До зазначених документів включено рапорт про насильство в сім'ї, який долучається до справи, а копія спрямовується до відповідного органу юстиції чи суду.

До рапорту вноситься інформація про статус стосунків сторін, їх стать, освіту та місце роботи чи форму діяльності, наявність дітей, час і дату надходження скарги, час початку розгляду, характеристика правопорушення, у випадку наявності або застосування зброї - іiі опис, перелік дій, ужитих працівником правоохоронного органу, наявність і строк чинності будь-якого попереднього ордера, який стосується сторін, інша інформація, необхідна для повноти висвітлення й аналізу обставин події [4, c.112].

При цьому зазначається, що запропонований перелік інформації є обов'язковим, але не вичерпним і може бути доповнений на розсуд працівника;

- у випадку необхідності чи за вимогою - надання постраждалим медичної допомоги чи забезпечення їх транспортування до медичної установи;

- за необхідності або за вимогою - забезпечення транспортування постраждалої особи (постраждалих осіб) до притулку чи іншого безпечного місця.

При цьому варто врахувати необхідність відвідування постраждалою особою (особами) місця проживання з метою забрання особистих речей; - у випадку, коли заявником 6 не постраждала, а інша особа, - вжиття заходів щодо забезпечення iï особистої 
безпеки; - затримання особи, яка вчинила насильство, в разі наявності передбачених законом підстав.

Модельний закон також містить положення про захисні накази, приписи та розпорядження. Законодавство передбачає, що «тут існує серйозна небезпека для життя, здоров'я та добробуту жертви, і вона навряд чи буде безпечною до винесення судового наказу, потерпілий/ позивач може звернутися до родича або працівника соціального забезпечення, до судді або магістрату, який покладає обов'язок надати надзвичайну допомогу, таку як тимчасова заборона, яка може бути винесеною стосовно порушника протягом 24 годин після настання насильства» [6].

Також варто наголосити, що основою національного законодавства України у сфері попередження та протидії насильству в сім'ї виступають міжнародні стандарти подолання домашнього насильства [18, с. 37].

До основних стандартів ООН належать:

1. Загальна декларація прав людини, прийнята і проголошена Резолюцією 217 А (III) Генеральної Асамблеї ООН від 10 грудня 1948 р.

2. Декларація про ліквідацію дискримінації стосовно жінок, затверджена Резолюцією Генеральної Асамблеї ООН № 2263 від 7 листопада 1967 р.

3. Конвенція про ліквідацію всіх форм дискримінації стосовно жінок, прийнята Генеральною Асамблеєю ООН 18 грудня 1979 р., ратифікована Указом Президії Верховної Ради УРСР від 24 грудня 1980 р. (чинна згідно із Законом України від 12 вересня 1991 р.№ 1543-XII «Про правонаступництво України»).

4. Загальні рекомендації №№ 12, 14 та 19 Комітету ООН з ліквідації дискримінації стосовно жінок.

5. Декларація ООН про викорінення насильства щодо жінок № 48-104 від 20 грудня 1993 р.

6. Пекінська Декларація та Платформа дій, ухвалена на Четвертій міжнародній конференції ООН зі становища жінок 15 вересня 1995 р.
7. Модельний закон «Про запобігання домашньому насильству», схвалений 2 лютого 1996 р. Комісією ООН з прав людини.

8. Резолюція A/HRC/7/L.22/REV про викорінення насильства щодо жінок від 27 березня 2008 року [18, с. 37].

Варто наголосити, що вивчення адміністративно-правового регулювання протидії насильству в сім'ї неможливе без порівняння норм національного законодавства 3 відповідними нормами адміністративного права зарубіжних країн, які встановлюють відповідальність за вказане діяння. Слід зауважити, що різноманітні прояви насильства в сім'ї є проблемою не тільки в Україні, але й у більшості зарубіжних країн [12,с. 162]. Так, згідно з дослідженням Всесвітньої організації охорони здоров'я поширеність фізичного та / або сексуального насильства щодо жінок варіюе від 29\% до 62\% [7]. При цьому Рада Европи припускає, що в державах-учасниках кожна четверта-п'ята жінка хоча $б$ один раз у своєму дорослому житті відчула фізичне насильство, і більш ніж кожна десята жінка була жертвою сексуального насильства із застосуванням сили [8]. Водночас потрібно зазначити, що дослідження адміністративного законодавства різних правових систем світу щодо питання відповідальності за вчинення насильства в сім’і та протидії цьому явищу дозволяє нам зробити висновок, що воно є досить неоднорідним.

У межах дослідження пропонуємо вивчити адміністративно-правові норми, які передбачають відповідальність за вчинення насильства в сім'ї та направлені на протидію йому, у державах англо-американського, романо-германського типу правових систем і деяких країнах пострадянського простору.

Вважаємо за необхідне розпочати з дослідження позитивного досвіду протидії насильству в сім'ї в державах англо-американського типу правових систем, зокрема СIIA, Канаді. Саме ці країни вже давно і наполегливо працюють у напрямку протидії насильству в сім'ї, приділяючи увагу питанням прав жінок і дітей, а тому накопичили значний досвід у цій сфері. Крім того, особлива правова система цих країн, заснована на увазі до деталей кожної справи, зумов- 
ᄉює актуальну практику правозастосування в досліджуваному нами питанні [5, с. 20].

На сьогодні США є державою 3 чітко виробленими механізмами протидії насильству в сім'ї, а тому може бути певним прикладом для запозичення позитивного досвіду в означеній сфері. Зрозуміло, що детально проаналізувати все законодавство СІІА та механізми протидії насильству в сім’ї в цій державі в межах одного монографічного дослідження неможливо. Однак, на нашу думку, потрібно відзначити найбільш важливі моменти протидії цьому явищу в законодавстві США.

1. Оновленим підходом у політиці США щодо реагування на насильство в сім’і є контроль, який забезпечує стратегію обов'язкового реагування. Контроль головним чином виражається в формі практики обов'язкового реагування на насильство в сім’ї, а саме: обов’язковий арешт, принцип обов'язкового судового провадження та обов'язкове інформування, яке передбачає, що медичний персонал зобов'язаний повідомляти про будь-які факти насильства в правоохоронні органи [9, с.17]. Також слід зазначити, що в багатьох штатах США ще наприкінці 60-х років минулого сторіччя було прийнято законодавство, яке зобов'язує громадян повідомляти владі про кожен випадок підозри в поганому поводженні 3 дітьми [10, с. 15]. При цьому вважаємо позитивною норму, передбачену$\S 29$ «Поліцейського закону» про те, що особi, яка вчинила насильство, на два тижні заборонено доступ у будинок і будь-які контакти 3 дружиною і дітьми [11], оскільки це є гарантією безпеки потерпілої особи [12,c. 163].

2. Необхідно зазначити, що одним із головних нормативно-правових актів у сфеpi протидії насильству в сім’ї в СІІА 6 Акт щодо боротьби 3 насильством в сім'ї, який діє насамперед на території штату Іллінойс. Цей нормативно-правовий акт передбачає можливість винесення щодо особи, яка вчинила насильство в сім’і, охоронного ордеру, який є подібним до захисного припису, винесення якого передбачено Законом України «Про попередження насильства в сім’ї». Під охоронним ордером розуміється офі- ційний припис, який виноситься судом, що забороняє винній у насильстві в сім'ї особі вчиняти певні дії щодо потерпілої особи або зобов'язує винну особу вчинити певні дії [13].

Позитивною рисою законодавства СІІА є передбачення в законодавстві декількох видів охоронного ордеру - надзвичайного охоронного, тимчасового охоронного та постійного охоронного. При цьому надзвичайний охоронний ордер видається суддею особі, якщо $є$ потреба при зверненні останньої до поліції, коли ще не відбулося судового засідання й немає можливості його терміново провести (наприклад, у нічний час). Тимчасовий охоронний ордер видається особі за ії зверненням до суду за наявності підстав на термін від 14 до 21 дня. У свою чергу, постійний охоронний ордер видається після тимчасового охоронного ордеру під час проведення судового розгляду, де на відміну від процедури видання тимчасового ордеру участь винної особи обов'язкова. Вислухавши потерпілу особу та обвинувачену в насильстві в сім'ї особу, суддя за наявності підстав може продовжити дію ордеру до 2 років [12, с. 163].

Також варто зазначити, що на відміну від захисного припису, який виноситься щодо особи, яка вчинила насильство, відповідно до законодавства України, охоронний ордер у СIIA передбачає великий спектр обмежень і зобов'язань для особи, яка вчинила насильство в сім’і. Серед цих обмежень необхідно звернути увагу на найбільш важливі на нашу думку: 1) надання виняткового права володіння житлом особі, яка стала жертвою насильства в сім'ї. Це обмеження може бути встановлено, якщо позивач, на відміну від відповідача, має право проживати в цьому приміщенні, а також у випадку, якщо обидва мають право проживати в цьому приміщенні, але рівень необхідності володіння саме цим житлом превалює в позивача; 2) надання позивачу права піклуватись про неповнолітніх дітей; 3) заборона відвідувати дитину або обмеження часу на їі відвідування; 4) грошова підтримка (зобов' язує відповідача виплачувати грошове утримання неповнолітнім дітям, які перебувають на піклуванні у позивача);- 
5) відшкодування збитків (зобов'язує відповідача відшкодувати збитки, що були завдані насильством); 6) заборона входу (якщо відповідач створює загрозу безпеці позивача чи дітей, йому забороняється входити i залишатися в оселі) [9, с.18-19].

На нашу думку, можливість отримання потерпілою особою надзвичайного та тимчасового охоронного ордеру до моменту розгляду справи в суді є важливою гарантією безпеки потерпілого від насильства в сім'ї та сприяє попередженню не лише адміністративних правопорушень у майбутньому, але й кримінальних злочинів. А тому вважаємо, що такий позитивний досвід CIIA може бути впроваджено в Україні, а норми законодавства США, що передбачають можливість видання різних видів охоронного ордеру, імплементовані в наше вітчизняне законодавство [12, с. 164].

3. Заслуговує на увагу досвід СІІА у протидії насильству в сім'ї в частині залучення поліції та служби шерифів для забезпечення виконання домовленостей між сторонами сімейного конфлікту (наприклад, супроводження зустрічей), контролю за виконанням обмежень у спілкуванні (зокрема за допомогою електронних пристроїв контролю за пересуванням) [5, с. 29].

4. У СШАА функціонує понад 200 спеціальних судів, які займаються справами про насильство в сім’ї. Дослідження показують, що спеціалізовані суди розглядають справи про домашне насильство більш ефективно, підвищують рівень законослухняної поведінки 3 боку порушників закону, призначають більш суворе покарання й виносять більший відсоток обвинувальних вироків. При цьому Відділ боротьби з насильством над жінками при Міністерстві юстиції США нещодавно розпочав спеціальну програму, яка називається Ініціатива суддівського наставництва. У межах цієї програми було визначено кращі судді, які можуть допомогти іншим розробити власні програми. Як наставники, ці судді будуть ділитися своїми знаннями та досвідом, приймаючи в себе представників інших судів і встановлюючи зв'язки між судами з метою впровадження передових методів роботи, удосконалення порядку судочинства, переймання відпо- відних програм і покращення можливостей судової системи штату щодо ефективного реагування в таких складних справах [14].

5. Важливу роль у протидії досліджуваному явищу в США відіграють різноманітні програми щодо запобігання всіх видів насильства у сім'ї. Серед них необхідно відзначити такі:

- програма «Здоров’я сім’ї Америки», відповідно до якої проблемні сім'ї відвідуються соціальними співробітниками на дому. При цьому експерти США вважають зазначену програму досить ефективною, оскільки відвідування сімей на дому є вельми перспективним і ефективним заходом у боротьбі з досліджуваним явищем. Вони зазначають, що сім'ї, у яких виявлено випадки зловживання психоактивними речовинами, наявні психічні захворювання або випадки домашнього насильства, слід відвідувати частіше для поширення інформації медичного характеру, боротьби з дитячими покараннями, підвищення якості взаємодії батьків і дітей [10, с.17];

- програма з реабілітації дітей в умовах комуни, метою якої 6 направлення дітей, що зазнали насильства в сім’і, до відповідних центрів реабілітації для надання їм різного роду допомоги. Так, центри-будинки розташовуються в сільській місцевості. Туди приїжджають діти, які мають емоційні і психологічні проблеми, пов'язані 3 жорстоким поводженням або зневагою їхніми інтересами, діти вилучені з сімей. Діти отримують індивідуальний 24-годинний догляд. Колектив лікарів, учителів, соціальних працівників та медиків створює їм сприятливе середовище, у якому $є$ довіра, почуття власної гідності і безпеки. Персонал під час реабілітації поєднує елементи психотерапії, освіти, мистецтва, музики, відпочинку та терапії. Діти зазвичай живуть у комуні від 3 місяців до 2 років. Після терапії діти можуть бути повернуті в прийомну сім'ю або до їхніх батьків чи опікунів [10, с.17].

6. Також варто звернути увагу на діяльність служб захисту дітей від насильства в сім’і у США. Так, відповідно до спільного національного Закону США «Про запобігання поганому поводженню 3 дітьми та ліквідації його наслідків» створено Національний 
Центр з проблем жорстокого поводження 3 дітьми та проблем запущених дітей, який сьогодні відповідальний за координацію служб захисту дітей, забезпечення практичної допомоги штатам і фінансування дослідницьких проєктів з питань насильства в сім'ї щодо дитини.

Сьогодні в США ефективно функціонує система служб захисту дітей, яка включає чотири аспекти діяльності: повідомлення, розслідування, втручання і завершення справи.

Що стосується першого аспекту, то слід зазначити, що в деяких штатах відповідно до закону обов'язком усіх громадянам 6 повідомляти про випадки поганого поводження 3 дітьми. В інших штатах це вимагається лише від медиків, психіатрів, учителів. Однак будь-яка людина може зробити таке повідомлення до відповідних органів. У законах штатів забезпечується недоторканність осіб, що роблять повідомлення, передбачається покарання за порушення такої конфіденційності [12, с. 166].

Після отримання повідомлення служби захисту дітей переходять до його розслідування, яке починається за необхідності негайно, а в менш загрозливих випадках це можна зробити протягом 48 годин. У СШІА службам захисту дітей наказано працювати 24 години на добу і щодня. Розслідування включає відвідування родини, обговорення повідомлення з батьками, спостерігання за дитиною й оцінювання умов іiї життя. Під час розслідування соціальний працівник має проводити регулярні медичні та психологічні огляди потерпілого. Медичні служби мають право госпіталізувати дитину в якості тимчасового захисту. У разі підтвердження насильства над дитиною заводиться справа про іï захист і ведеться до того часу, поки це необхідно. У разі якщо дитині загрожує серйозна небезпека, соціальний працівник мусить негайно ізолювати дитину від сім'ї [12, с. 167].

Наступним етапом допомоги таким родинам $\epsilon$ втручання, під яким слід розуміти надання родинам конкретної послуги (грошової допомоги сім'ї, наприклад), підтримку (домогосподарство, денний догляд, медичне обслуговування, класи для батьків) i терапію індивідів, сімейних пар, загалом сімей.

Останнім етапом діяльності служби захисту дітей $є$ завершення справи в разі покращення ситуації в сім'ї, або ж, коли робота соціальних робітників не дала позитивних результатів, діти ізолюються і поміщаються в прийомні установи. У такому випадку справа про захист дитини закривається i відкривається нова справа про утримання дитини в приймальному закладі.

Треба зауважити, що сьогодні основна увага фахівців США в означеній сфері направлена на соціально-терапевтичну діяльність для збереження сім'ї, а не на каральні заходи щодо батьків [10, с.18-19].

Отже, можемо констатувати, що США має ефективну систему попередження та протидії насильству в сім'ї, деякі заходи якої доцільно запровадити в Україні, а окремі норми законодавства США у цій сфері - імплементувати у вітчизняне законодавство, що регулює відповідні питання.

Окремий інтерес для нашого дослідження має законодавство та система заходів протидії насильству в сім’ї в Канаді. Слід зазначити, що Канаді належить одне 3 провідних місць у світі серед країн, які ведуть боротьбу з насильством у сім'ї. При цьому зазначимо, що з початку 1997 року в Канаді розпочинається курс на нову політику у сфері протидії насильству в сім'ї - політику «нульової терпимості». Суть цієї політики зводилася до такого: жоден випадок насильства в сім'ї не має залишитися без уваги і покарання, що має діяти на всіх рівнях державної влади, у роботі громадських організацій і кожного члена суспільства. Слід зазначити, що в Канаді немає спільного федерального закону з протидії насильству в сім'ї, проте чотири провінції окремо запроваджують спеціальне законодавство з попередження цього явища. Ці нормативні акти доповнюють Кримінальний кодекс Канади в частині запровадження захисту постраждалих від насильства [15, с. 44].

У межах нашого дослідження, звичайно, неможливо розглянути всі особливості протидії насильству в сім’ї в Канаді. Однак вважаємо за необхідне звернути увагу на головні напрямки роботи у сфері протидії на- 
сильству в сім’ї та допомоги постраждалим від нього:

1) у Канаді створено гнучку та розгалужену систему ордерів і приписів, що дозволяють терміново втрутитися в інцидент насильства, убезпечити постраждалих від контактів 3 агресором, увійти до помешкання представникам правоохоронних органів, евакуювати постраждалих, установлювати спостереження за оселею. Так, у провінції Альберта 1998 року було прийнято Акт захисту від насильства в сім’ї, який забезпечує захист усіх членів сім’і - жінок, чоловіків, дітей, літніх людей. Відповідно до цього Акта в провінції діють три форми захисту: 1) охоронний ордер (коли потрібна негайна допомога); 2) королівський судовий ордер захисту; 3) ордер, що дає право на вхід до житла [16];

2) заслуговує на увагу система термінового реагування на випадки насильства в сім'ї (Domestic Violence Emergency Response System - DVERS) [16]. Постраждалі безкоштовно отримують портативну апаратуру, за допомогою якої можна подати сигнал небезпеки, який буде переданий до поліції як дзвінок надзвичайної важливості. Відзначимо, що DVERS стала першою системою такого роду в Північній Америці й наразі широко застосовується в Канаді (більше 30 міст) і США (близько 150 міст);

3) у Канаді створено велику систему 3 близько 400 так званих шелтерів (притулків), які здійснюють допомогу жертвам насильства в сім’ї і надають їм такі послуги: консультації, курси психологічної реабілітації, освітні послуги, послуги юриста, 24-годинну кризову телефонну лінію та інші [15, c.45];

4) у Канаді діє чимало різноманітних програм, направлених на протидію насильству в сім’ї. Насамперед слід указати на превентивні освітні програми, під якими мається на увазі багатостороння програма для дитячих садків і шкіл, спрямована на збільшення рівня громадської обізнаності про жорстоке поводження і нехтування дітьми. Завдяки цій програмі діти, батьки, педагоги, адміністрація навчальних закладів отримують навички особистої безпеки й можуть навчити інших. Слід також зазначити, що при Комітеті з профілактики насильства над дітьми функціонує спеціальний Робочий комітет суспільства та представників агентств для підтримки освітньої превентивної програми. Аюди різних професій і структур залучені в роботу цього Комітету. Навчальна програма підтримується урядом, приватними особами та організаціями.

Уведено в дію також програму підтримки дітей-жертв сексуального насильства. У законодавчій сфері Комітет об’єднує всі свої зусилля на отримання доповідей з поліції і НВО щодо всіх випадків насильства над дітьми [10, с. 21].

У свою чергу, досить дієвими є такі програми:

- програма групових сімейних конференцій, суть якої зводиться до того, що для розв'язання проблеми насильства у шлюбі або проти дитини в сім'ї залучається вся родина (старше покоління, молодші та ін.);

- програми відновного правосуддя щодо протидії насильству в сім'ях корінного населення [17], а також підтримки цілісної моделі надання всього спектру послуг постраждалим жінкам - представницям корінного населення, розвиток мережі перекладачів;

- програми корекції поведінки кривдників. У провінціях Канади (Манітоба, Альберта, території корінного населення та ін.) розроблені та запроваджуються програми для кривдників: групове консультування (шістьма мовами); 84-годинна програма інтенсивної терапії для умовно звільнених від покарання (тих, хто проходить пробацію); 300-година програма для тих, хто відбуває покарання за насильницькі злочини. Існують також і програми індивідуального консультування;

- програми довготермінової підтримки й відновлення дітей - жертв і свідків домашнього насильства - із залученням служб опіки, медиків, освітян тощо. Ці програми передбачають зокрема розвиток мережі фостерних сімей, де дитина може перебувати протягом реабілітаційного періоду, а також доки не буде винесене рішення стосовно виховного потенціалу сім'і та повернення / позбавлення опіки щодо дитини [15, c. 46]; 
5) у Канаді в різних провінціях створено спеціальні суди, які розглядають випадки насильства в сім'ї: у Вінніпезі функціонує Суд у справах насильства в сім'ї, в Онтаріо також здійснюють свою діяльність два типи спеціальних судів у справах насильства в сім'ї: перші для розгляду більш простих випадків, зокрема таких, коли закон порушено вперше, а другі - більш серйозних випадків, які вимагають більш суворого покарання. Така спеціалізація допомагає покращити якість судового провадження та більше сприяє захисту інтересів жертв насильства в сім'ї [9, с. 21];

6) у Канаді основну відповідальність за розвиток політики і системи соціальних служб, освіти та охорони здоров'я несуть уряди провінцій і територій. Ці уряди визначають тип необхідних служб підтримки для жінок, що піддаються насильству в сім'ї, визначають розміри фінансування [12, c. 167].

\section{Висновки}

Проаналізовані зарубіжний досвід правової протидії насильству в сім'ї та домашньому насильству в країнах СШІА Та Канаді і положення модельного законодавства ООН щодо протидії цим видам насильства можуть слугувати серйозною правовою основою для розвитку вітчизняного права та правозастосовної практики, а також накопичений досвід цих країн у сфері протидії насильству в сім'ї 6 позитивним і корисним для запозичення його боротьби 3 досліджуваним явищем в Україні.

\section{入ітература}

1. Кузьменко Ю.В. Протидія домашньому насиллю: новели законодавства України. Право і суспільство. № 2 / 2019. С. 131-136.

2. Про попередження насильства в сім'ї: закон України від 15.11.2001 № 2789-III.. База даних (БД) «Законодавство України» / Верховна Рада (ВР) України. URL: http:// zakon.rada.gov.ua/laws/show/2789-14.

3. Проект Закону про запобігання та протидію домашньому насильству : від 20.10.2016 № 5294 / ініціатор: В. Б. Гройсман // БД «Законодавство України» / ВР
України. URL: http://w1.cl.rada.gov.ua/pls/ zweb2/ webproc4_1pf3511=60306.

4. Легенька М.М. Зарубіжний досвід протидії насильству в сім’ї та можливості використання в Україні. ПРАВО І БЕЗПЕКА. 2017. № 4 (67). С. 111-116.

5. Міжнародний досвід попередження та протидії домашньому насильству : монографія / А. О. Галай, В. О. Галай, А. О. Головко та ін.; за заг. ред. А. О. Галая. Київ : КНТ, 2014. $160 \mathrm{c}$.

6. UN Handbook for Legislation on Violence against Women // The Advocates for Human Rights : сайт. URL: http://www.stopvaw.org/ united_nations_model_legislation.

7. WHO Multi-country Study on Women's Health and Domestic Violence against Women, (WHO, 2005), p. 5 URL: http:// www.who.int/reproductivehealth/publications/ violence/24159358X/en

8. Fact Sheet, Council of Europe Campaign to Combat Violence against Women, including Domestic Violence, at [Електронний pecypc]. - Режим доступу : http: // www.coe.int/t/dg2/ equality/domesticviolencecampaign/ Fact_ Shee_en.asp.

9. Діяльність служби дільничних інспекторів міліції щодо профілактики насильства над дітьми й дорослими членами сім'ї: [навчально-методичний посібник] / [Блага А.Б., Журавель Т.В., Заброда Д.Г., Мілорадова Н.Е.] ; за ред. Г.О. Христової. - К. : ТОВ “ВПК “ОБНОВА”, 2012. - 140 с.

10. Исмуханова Г. Обзор международного опыта по профилактике насилия и жестокого обращения в отношении детей и семей в рамках программы «Равенство перед законом: доступ к правосудию в Центральной Азии» URL: http://www. bala-kkk.kz/sites/default/files/upload/files/ B0.pdf.

11. За честь семьи // Europa-Express. № 40 (396). 03.10.-09. 2005. C. 74.

12. Адміністративно-правове регулювання протидії насильству в сім'ї: монографія // Ганна Олександрівна Горбова, Валентин Васильович Галунько. - К. : Інститут публічного права, 2016. 226 с.

13. Illinois Domestic Violence Act and other Significant Laws Affecting Domestic Violence. - Illinois Coalition Against Domestic Violence 


\section{Адміністративне право}

\section{АНОТАЦІЯ}

Обгрунтовано актуальність вивчення та врахування в нормотвориій діяльності міжнародних стандартів протидї домашньому насильству. Проаналізовано модельне законодавство ООН про домашне насильство та перспективи впровадження його норм у вітиизняну практику. Узагальнено досвід законодавчого забезпечення боротьби з домашнім насильством у краӥнах Европи з точки зору можливостей його використання в Украӥні.

Ключові слова: запобігання та протидія домашнъому насильству, міжнародні нормативно-правові стандарти, законотвориість, міжнародний досвід, захисний припис.

Legal Institute, 2001. 134 p. URL: https:// en.wikipedia.org/wiki/Domestic violence.

14. Блог посольства СІША в Москве Борьба с домашним насилием в США. URL: http://embassy-voices.livejournal.com/28143. html.

15. Кочемировська О. О. Стандарти надання соціальних послуг особам, які постраждали від насильства в сім'ї: міжнародний досвід та рекомендації для України / Кочемировська О.О., Христова Г.О. ; наук. ред. О. Кочемировська ; заг. ред С. Павлиш. К.: Запоріжжя: Друкарський світ, 2011.$228 \mathrm{c}$.

16. Забелина Т. Ю. Канада и проблема насилия в семье: двадцать лет борьбы [Електронний ресурс] / Забелина Т.Ю., Исраелян E.B., Шведова H.A. URL: http: // www.owl.ru/ win/research/kanada.htm.

17. Ross R. (1996) Returning to the Teachings: Exploring Aboriginal Justice. Toronto: Penguin Group Canada. [in G. Johnstone (2003) A Restorative Justice Reader. Cullompton, Devon: Willan].

18. Насильство в сім'ї та діяльність органів внутрішніх справ щодо його подо-

\section{SUMMARY}

The relevance of studying and taking into account international standards for combating domestic violence in rule-making activities is substantiated. The UN model legislation on domestic violence and the prospects of implementing its norms in domestic practice are analyzed. The experience of legislative support of the fight against domestic violence in European countries in terms of the possibilities of its use in Ukraine is summarized. Key words: prevention and counteraction to domestic violence, international normative legal standards, law-making, international experience, protective order. The study of administrative and legal regulation of combating domestic violence is impossible without comparing the rules of national law with the relevant rules of administrative law of foreign countries, which establish responsibility for this act. It should be noted that various manifestations of domestic violence are a problem not only in Ukraine but also in most foreign countries. It is the United States and Canada that have long and persistently worked to combat domestic violence, focusing on women's and children's rights, and have accumulated considerable experience in this area. In addition, the special legal system of these countries, based on the details of each case, determines the current practice of law enforcement in our study.

Key words: prevention and counteraction to domestic violence, international legal standards, legislation, international experience, protective order.

лання: навчально-методичний посібник для курсантів вищих навчальних закладів МВС України /Укладачі: Запорожцев А.В., Аабунь А.В., Заброда Д.Г., Басиста I.В., Дроздова I.В., Брижик В.О., Мусієнко О.М. Київ, 2012. 246с. 